DOI https://doi.org/10.30525/978-9934-26-110-7-7

\title{
ВАРІАНТИ УКРАЇНСЬКОЇ ЛАТИНИЦІ: ІСТОРІЯ ФОРМУВАННЯ
}

\author{
Пересада С. I. \\ магістр, \\ асистент кафедри германської філології \\ Донеиький начіональний університет імені Василя Стуса \\ м. Вінниця, Україна
}

Латиниця (від лат. Latinus - латинський, римський) $€$ однією 3 найдавніших систем письма, якою користувалися ще давні римляни і яка лягла в основу письма більшості народів Західної Європи. Латиниця, як відомо, $є$ відгалуженням етруського алфавіту, що походить від грецького письма [3, с. 291]. Більшість слов'янських мов, а саме боснійська, кашубська, польська, сілезька, серболужицька, словацька, словенська, хорватська та чеська запозичили латинський алфавіт, а такі мови, як сербська, чорногорська та білоруська, користуються паралельно двома абетками. Утім хоч східнослов'янські мови, до яких належать російська, білоруська і українська, не змінили кирилиці на латиницю, однак використовують ії графіку.

Мета цієї наукової розвідки - окреслити в загальних обрисах спроби переходу української лінгвокультури з кирилиці на латиницю та описати основні варіанти української латинки. Мета зумовлює такі завдання: 1) схарактеризувати варіанти латиниці, що були створені для українського мовного простору; 2) дати стислу історичну характеристику кожному запропонованому виду української латиниці. Об'єкт дослідження - латинська графіка українського мовного простору. Предмет - алфавіти української латиниці кінця XIX - початку XXI ст.

В Україні простежувалися спроби перейти з кирилиці на латиницю, а проблеми конкуренції та заміни цих двох графічних систем були описані в українському мовознавстві наприкінці XIX - на початку XX століть Іваном Франко та Маркіяном Шашкевичем. Розгляд цього питання не полишають і сучасні мовознавці, приділяючи чимало уваги проблемам функціювання графем латиниці в українському дискурсі. Серед таких сучасних учених Сергій Вакуленко, Тетяна Космеда, Міхаель Мозер, Василь Німчук, Лілія Соболь, Богдан Рицар та інші.

Лінгвісти XIX ст. дискутували навколо питання про переведення української мови з кириличної основи на латиницю. Так, 
Йосип Лозинський переконував, що «для слов'янських народів було би ліпше прийняти одну азбуку, а власне латинську, яка ввела би їх безпосередньо в круг європейських культурних народів і полегшила би тим народам знайомитися 3 письменством всіх слов'янських племен» [2, с. 289,]. Але в той час, коли деякі мовознавці підтримували процес латинізації української мови, більшість культурних діячів України, зокрема Яків Головацький, Денис Зубрицький, Йосип Левицький, Іван Франко, Маркіян Шашкевич та ін., стояли на позиції, що цього робити не потрібно. М. Шашкевич, наприклад, у своїй праці «Азбука і абецадло», стверджував, що графеми латиниці в різних народів мають різне чи навіть протилежне значення. Тому «кожен народ буде читати українське письмо відповідно до свого правопису і буде творити 3 українських слів незрозумілі нісенітниці, страшні для вуха слов'янина, а звідси виникне не зовсім правильна думка про українську мову» $[5$, c. 115$]$.

У 20-тих та на початку 30-тих років ХХ століття в СРСР проходить кампанія латинізації, у ході якої на латинську абетку перейшли 69 мов, але що стосується української мови, то дискусії продовжувалися. У 1927 році в Харкові відбулася Всеукраїнська правописна конференція, під час якої Майк Йогансен, Борис Ткаченко та Михайло Наконечний гостро поставили питання латинізації та запропонували прийняти латинський алфавіт як частину правопису, але після завершення конференції ця пропозиція відкинулася 3 перевагою в один голос «проти». Але на сьогодні для задоволення різних потреб існує необхідність використання українських варіантів латиниці. Запропоновано чотири основних варіанти, серед яких:

1) «абеиадло». Це перший варіант української латиниці, в основі якої лежить польська графіка. Ї̈̈ запропонував український мовознавець, етнограф, публіцист, теолог та громадський діяч Й. Лозинський. У 1834 p. він закликав латинізувати український алфавіт у науковій студії «O wprowadzeniu abecadła polskiego do piśmiennictwa ruskiego» («Про запровадження польської абетки в руську писемність»), започаткувавши цим «азбучну війну» в Галичині [див.: 3, с. 332]. 3 метою наочного практичного втілення своєї ідеї він опублікував абецадлом власної редакції і етнографічну працю «Ruskoje wesile» (1835). Однак, ця система не набула широкого визнання та не ввійшла до загального вжитку, оскільки викликала перший спалах «азбучної війни»;

2) «їречківка», або правопис Їречка. Це наступний проєкт, що був запропонований чеським славістом Йозефом Їречеком за дорученням цісарсько-королівського міністерства культури і освіти Австрії. Його 
опубліковано на початку травня 1859 року. Це була брошура під заголовком «Über der Vorschlag das Ruthenische mit lateinischen Schriftzeichen zu schreiben. Im Auftrage des k. k. Ministeriums für Cultus und Unterricht verfasst von Jozeph Jireček, Wien. Aus der keizerlich königlichen Hof- und Staatsdruckerei 1859» («Про пропозицію писати по-українськи латинськими літерами. За дорученням цісарсько-королівського міністерства культури і освіти через Йосифа Їречка. Відень, урядова державна друкарня 1859») [див. про це: 4, с. 4]. На відміну від абецадла, іречківка базувалася переважно на чеському правописі 3 кількома польськими літерами. Підтримуючи цей проєкт абетки 1880 року, Михайло Драгоманов видав латинізовану версію «Кобзаря». Але ця ідея Й. Їречека зіткнулася із супротивом суспільства, викликала хвилю масових протестів та призвела до другої хвилі боротьби української громадськості Галичини проти полонізаторських спроб латинізувати український алфавіт [див.: 1, с. 4]. Проте саме цей варіант української латиниці став основою для подальших розробок XX та XXI ст.;

3) гаєвиця. Нові спроби адаптації латинського письма до української мови спричинив варіант латинської абетки, що був розроблений хорватським поетом та лінгвістом Людевитом Гаєм на основі чеського правопису. Уперше його було запропоновано в праці «Kratka osnova horvatsko-slavenskog pravopisanja» («Коротка основа хорватськослов'янського правопису»). Ця система лягла в основу наукової транслітерації кирилиці, а також міжнародного стандарту ISO9;

4) англійська латиниця. У XXI столітті варіантом української латинки стала система літер, що була розроблена термінологічною комісією природничих наук Київського університету. Вона базується на фонетикографічних традиціях української та споріднених слов'янських мов. Затвердивши принципи транслітерації, що були розроблені представниками ТКПН, у 2000 році академічна транслітераційна комісія, яка була створена розпорядженням Президента НАН України Бориса Патона, висунула пропозицію (а) використати цю розробку як основу національного стандарту української латиниці та (б) у майбутньому включити іï до українського правопису з рекомендацією використання для транслітерації.

Висновки. Неодноразові спроби переводу графіки української мови на латиницю, «конкуренція» латиниці й кирилиці простежується в українському мовному просторі 3 XIX століття й продовжується до сьогодні, що й спричинило появу різних проєктів української латиниці. До основних варіантів української латиничної абетки належать чотири, однак існує й багато інших проєктів, що не привернули належної уваги: 
насамперед це інші проєкти, створені на основі пропозицій Й. Їречека, та розробки Івана Лучука, Сергія Мельника, Максима Лагоди. Проте жодна 3 них до сьогодні не замінила кириличного алфавіту в Україні, а латиниця використовується для інших функцій, насамперед для транслітерації, моделювання образності, атракційності художнього та публіцистичного тексту (дискурсу) та ін., що потребує докладного опису.

\title{
Література:
}

1. Історія української мови: словник-довідник / ідея, упорядкування та окремі статті В. В. Денисюка. Умань. Візаві. 2013. 387 с.

2. Космеда Т. А. Комунікативна компетенція Івана Франка: міжкультурні, інтерперсональні, риторичні виміри: монографія. Львів. ПАІС. 2006. 328 с.

3. Українська мова : енциклопедія / редкол.: В. М. Русанівський та ін.; НАН України, Ін-т мовознав. ім. О. О. Потебні, Ін-т укр. мови. Київ. Вид-во "Українська енциклопедія" ім. М. П. Бажана. 2004. 820 с.

4. Франко I. Азбучна війна в Галичині 1859 р., Франко І. Твори в 50 томах. Київ. Наукова думка. 1986. Т. 47. С. 549-650.

5. Шашкевич М. Азбука і абецадло. Письменники Західної України 30-50-х років ХІХ ст. Київ. Наукова думка. 1965. С.113-120.

DOI https://doi.org/10.30525/978-9934-26-110-7-8

\section{АВТОПОБАЖАЛЬНІ КОНСТРУКЦЇ̈ В СУЧАСНІЙ УКРАЇНСЬКІЙ МОВІ}

\author{
Умрихіна Л. В. \\ кандидат філологічних наук, \\ доцент кафедри украӥнознавства і лінгводидактики \\ Харківський національний педагогічний університет \\ імені Г. С. Сковороди \\ м. Харків, Україна
}

Автопобажальні конструкції представлені конструкціями структурних схем $\quad \mathrm{N}_{1} \mathrm{Vf}_{\text {des } 1 \mathrm{sg} / \mathrm{p} l}, \quad \mathrm{~N}_{1} \mathrm{Vf}_{\text {des } 1} \mathrm{~N}_{1 / 5}, \quad \mathrm{~N}_{1} \mathrm{Vf}_{\text {deslsg/pl(cop) }} \mathrm{Adj}_{1 / 5}$, $\mathrm{N}_{1} \mathrm{Vf}_{\text {des1 } 1 \mathrm{sg} / \mathrm{pl}(\mathrm{cop})}$ Part $_{1 / 5}, \mathrm{~N}_{1} \mathrm{Vf}_{\text {des } 1 \mathrm{sg}(\mathrm{cop})} \mathrm{N}_{2,3 \ldots}$.

Автопобажальні конструкції структурної схеми $\mathrm{N}_{1} \mathrm{Vf}_{\text {des1sg/pl }} \epsilon$ граматичною реалізацією вихідної конструкції структурної схеми $\mathrm{N}_{1} \mathrm{Vf}$ у формі синтаксичного ірреального способу, організованого через 